\title{
EFFECT OF HEALTH PROMOTION MEDIA ON HIV/AIDS CONTROL AND PREVENTION BEHAVIOR AMONG CHURCH YOUTH IN TIMOR TENGAH UTARA, EAST NUSA TENGGARA
}

\author{
Handrianus Akoit'), Intje Picauly²) \\ ${ }^{1)}$ Health Vocational high school, Kefamenanu District, North-East Timor \\ 2)Masters Program in Public Health, Nusa Cendana University, Kupang
}

\begin{abstract}
Bacground: Worldwide there were approximately 36.7 million people living with HIV/AIDS by the end of 2016. Of these, 2.1 million were adolescents. An estimated 1.8 million individuals worldwide became newly infected with HIV in 2016, or equivalently about 5,000 new infections per day. This study aimed to assess the effectiveness of promotion media on HIV/AIDS control and prevention behavior among church youth in Timor Tengah Utara, East Nusa Tenggara.

Subjects and Method: This was a quasi-experiment before and after study with no control group design. The study was conducted at Kefamenanu, Timor Tengah Utara, East Nusa Tenggara, on June to July 2018. A total sample of 250 church youth was selected for this study by total sampling. The independent variable was promotional media on HIV/AIDS including video and poster. The dependent variable was preventive behavior. The data were collected by questionnaire. Mean different effect of promotional media including film and poster was tested by t-test.

Results: Mean score of preventive behavior after information by video (97.71 points) was higher than before (90.20 points) and it was statistically significant ( $\mathrm{p}<0.001)$. Mean score of preventive behavior after information by poster ( 94.85 points) was higher than before (91.64 points), and it was statistically significant ( $\mathrm{p}<0.001)$.

Conclusion: Promotional media by video and poster is effective to improve HIV/AIDS preventive behavior among church youth.
\end{abstract}

Keywords: promotional media, HIV/AIDS, prevention behavior, church youth.

\section{Correspondence:}

Handrianus Akoit. Health vocational high School, Kefamenanu District, North-East Timor. Email: picaulyince@yahoo.co.id. Mobile: 082237145517.

The $5^{\text {th }}$ International Conference on Public Health Best Western Premier Hotel, Solo, Indonesia, February 13-14, 2019 | 178 https://doi.org/10.26911/theicph.2019.02.23 